\title{
Local Wisdom of Smoked Fish Processing as Tourism Product in Situbondo Regency
}

\author{
Ika Junianingsih ${ }^{1}$, Luchman Hakim ${ }^{2}$, Nuddin Harahab ${ }^{3}$ \\ ${ }^{1}$ Master Program of Environmental Resources Management, Graduate Program, University of Brawijaya, Malang \\ ${ }^{2}$ Department of Biology, Faculty of Mathematics and Natural Sciences, University of Brawijaya, Malang \\ ${ }^{3}$ Department of Fisheries Socio-Economics, Faculty of Fisheries and Marine Sciences, University of Brawijaya, Malang
}

\begin{abstract}
Marine and fisheries resources in Situbondo Regency were potential to supports seafood processing, e.g. traditional smoked processing of mackerel tuna (Euthynnus affinis Cantor) based on local wisdom. This research was aimed to assess and analyzes: the processing of smoked mackerel tuna based on local wisdom, public perception towards the processing of smoked mackerel tuna, and the quality of smoked mackerel tuna. The research carried out on January to April 2014, in Jangkar Village, Situbondo regency. The study included depth interview from key persons with questionnaire and organoleptic test. The public perception on smoked mackerel tuna was taken by questionnaire from 85 respondents, whereas the quality of smoked mackerel tuna was analyzed with laboratory proximate test. Result of this research showed that smoked mackerel tuna processing used traditional smoking instrument and fuel material. The smoking stall used several banana midrib stem above the furnace that made of cement and bricks, while the fuel use coconut coir which created the typical flavors of the smoked mackerel tuna. The average organoleptic value of the smoked mackerel tuna appearance is 7.89 (intact, clean, brown, very shiny specific type), flavors of 8.24 (less fragrant, smoked enough, without additional disturbing odor), taste of 8.41 (delicious, savory), texture of 7.40 (solid, compact, fairly dry, tight inter-flesh tissue), and colour of 7.20 (attractive, specific, shiny brown colour type). Public perception showed that the community knowledge on smoked mackerel tuna processing is good, creates good flavors of smoked mackerel tuna and favored by the community, thus also encourage the community to support the conservation of this traditional smoked processing. Lab analysis showed that the proximate value of $0.99 \%$ carbohydrates, $29.59 \%$ protein, $1.14 \%$ fat, $2.89 \%$ mineral, $1.88 \%$ ash, and $63.4 \%$ water. Processing of smoked mackerel tuna as tourism product of Situbondo Regency is worth and it has been given benefits to the increasing of community welfare, thus it need to be preserved to become sustainable.
\end{abstract}

Keywords: culinary product, public perceptions, smoked mackerel tuna, traditional seafood processing.

\section{INTRODUCTION}

Sea and coastal resource in Indonesia are greatly potential, including its non-natural resources (such as minerals) and its natural resources; especially fisheries. It is supported by the archipelago which has a long coastline of $81,000 \mathrm{~km}$ and sea width area of 5.8 million $\mathrm{km}^{2}$, thus reserved abundant natural resources for the community life necessity [1]. Marine fisheries sub-sector greatly contributes to the additional value of fisheries sector, e.g. aquaculture, hatchery, and well processed products of marine and fishery; both modern and traditional [2].

Marine fishery products processed in modern and traditional way, which essentially applying the concepts of efficiency and conservation in the utilization of natural resources [3]. Marine fishery products which processed traditionally are salted fish, boiled fish, smoked fish, and fermented products [3]. Traditional fish process-

\footnotetext{
* Correspondence address:

Ika Junianinsih

Email : ikajunia05@yahoo.co.id

Address : Graduate Program, University of Brawijaya, Jl. Mt. Haryono No. 169 Malang 65145
}

ing is prospective to be more mainly developed than the modern process, such as freezing and canning [5], because traditional processing is low cost and use simple equipment.

Smoking on fish as a form of processed marine fisheries, is a well known product called exotic indigenous food. It means that this smoked fish products are traditionally processed in a specific area and will be difficult to be found in other areas. It also become a primary regional commodities from the origin area $[5,6,7]$. As one example, smoked mackerel tuna (Euthynnus affinis Cantor) called Jangkar in Situbondo, East Java. Jangkar become the culinary tourism product with a distinctive flavor that strongly recommended when visiting the areas of Situbondo [8]. It has a different flavor to the smoked fish production of some other areas, such as Sumatra (Salai), Maluku (Asar), Sulawesi (Kayu), and Central Java $(P e)$. It is due to the flavor and odor characteristic of the product that influenced by the smoking process, the use of raw materials, the use of fuel and other processing factors. These characteristics are the 
affecting factor the development of business prospects of the smoked fish processing.

Smoked fish in Situbondo area processed traditionally, from generation to generation by applying their local wisdom. Local knowledge is used in the processing of smoked mackerel tuna, e.g. smoking process and the fuel used. Local people use of banana midrib stem above the stove made of cement and brick. This way of smoking is believed to be able to produce a distinct different flavor to the product, even without salting and the addition of food additive. Local people only use the burning coconut coir as fuel for producing the smoke. As explained by Haras [9], the types of wood that used to produce smoke will affect the product quality.

Good type of wood for smoking is slowburned hardwood, contained many flammable compounds, e.g. cellulose, hemicelluloses, lignin, and acid [10]. Coconut coir and shell is type of widely used hard wood to produce both gas and liquid smoke because its composition of lignin, cellulose, and methoxyl contribute a good organoleptic properties [11].

The primary raw material of smoked fish in Situbondo is mackerel tuna, because it is the main fish catches in the area. Department of Fisheries and Marine of Situbondo [2] reported the fish catches of 2012 reached 6,092.19 tons includes $1,302.580$ tons of mackerel tuna, 1,695.023 tons of Decapterus fish, 774.740 tons of Nemipterus japonicus Bloch fish, and other fish species. Pelagic fish (tuna, mackerel, mackerel tuna, skipjack, snapper, etc.) are commonly used as a raw material of smoked fish $[12,13]$.

There are other procedures for smoked fish processing such as kitosan for dumbo catfish [14], liquid smoke on mackerel tuna [15], and different liquid smoke on mackerel tuna [16]. Meanwhile, traditional processing of smoked mackerel tuna in Jangkar Village, Situbondo Regency has not been assessed yet. Therefore, this study aimed to assess the local wisdom on smoked processing of mackerel tuna. We also assess the public perception on the smoked processing of mackerel tuna and assess the quality of it. Our study was expected to assist the development of the smoked processing units and conserved this processing as tourism products which based on local wisdom.

\section{MATERIALS AND METHODS}

The research was conducted from January to April 2014. Observation and sampling of smoked mackerel tuna is conducted in Jangkar Village,
Situbondo Regency. Jangkar Village located in $\pm 28 \mathrm{~km}$ of east Situbondo, in latitude of $0-500 \mathrm{~m}$ asl with 6,700 ha warea. It is divided into eight villages with 36,684 persons is fisherman [2]. The research was conducted in three stages analysis of aspects, i.e. local knowledge of smoked mackerel tuna processing, public perception on smoked mackerel tuna products, and the quality of smoked mackerel tuna.

\section{Traditional Smoked Processing}

Primary data retrieved by direct observation on the smoking process and depth interviews to keynote speakers as the owner of the smoked fish processing units. Interviews using a direct questionnaire on the following objects: fish raw material (type and fish resources); fuel material (type and fuel resources); fish processing methods; smoking duration (time); other processing handling (salting, aeration, and packaging). The level of consumer preference towards smoked mackerel tuna assessed by organoleptic test to 85 respondents (Table 1). Organoleptic scale is in the range of 1-9 [17].

Table 1. Organoleptic Criteria for Comsumer Preference

\begin{tabular}{|c|c|}
\hline Specification & Score \\
\hline \multicolumn{2}{|l|}{ 1. Appearance } \\
\hline - Intact, clean, strong shiny brown specific color. & 9 \\
\hline - Intact, clean, shiny brown specific color. & 7 \\
\hline - Intact, clean, brown, faint. & 5 \\
\hline - Unintact, dark brown, faint. & 3 \\
\hline - Unintact, dark brown, very faint. & 1 \\
\hline \multicolumn{2}{|l|}{ 2. Flavor } \\
\hline - Fragrant, adequate smoke, no extra disturbing odor. & 9 \\
\hline - Less fragrant, adequate smoke, no extra disturbing odor. & 7 \\
\hline - Neutral, slight extra odor. & 5 \\
\hline - Strong extra odor, ammonia odor and putrid. & 3 \\
\hline - Reek, strong ammonia odor and putrid. & 1 \\
\hline \multicolumn{2}{|l|}{ 3. Taste } \\
\hline - Delicious, savory. & 9 \\
\hline - Delicious, less savory. & 7 \\
\hline - Undelicious, unsavory. & 5 \\
\hline - Undelicious with disturbing extra flavored. & 3 \\
\hline - Musty. & 1 \\
\hline \multicolumn{2}{|l|}{ 4. Texture } \\
\hline - Solid, compact, dry, tight inter-tissue. & 9 \\
\hline - Solid, compact, fairly dry, tight inter-tissue. & 7 \\
\hline - Less Dry, loose inter-tissue. & 5 \\
\hline - Soft, easyly detached tissue. & 3 \\
\hline - Very soft, easyly detached tissue. & 1 \\
\hline \multicolumn{2}{|l|}{ 5. Colors } \\
\hline - Very attractive, strong shiny brown specific color. & 9 \\
\hline - Attractive, shiny brown specific color. & 7 \\
\hline - Less attractive, brown, faint. & 5 \\
\hline - Unattractive, dark brown, faint. & 3 \\
\hline - Very Unattractive, dark brown, faint. & 1 \\
\hline
\end{tabular}




\section{Assessmet of Public Perception}

Consumer and public perceptions were randomly sampled through direct surveys and interviews to consumers and community. The result of the interview was scored using Likert Scale, with formula [18]:

$$
A \mathbf{i}=\frac{(\mathrm{a} .5)+(\mathrm{b} .4)+(\mathrm{c} .3)+(\mathrm{d} .2)+(\mathrm{e} .1)}{\mathrm{a}+\mathrm{b}+\mathrm{c}+\mathrm{d}+\mathrm{e}}
$$

Description:

$\mathrm{Ai}=$ public perception on statement- $\mathrm{i}$

$a=$ number of respondents who scored 5

$b=$ number of respondents who scored 4

$\mathrm{c}=$ number of respondents who scored 3

$\mathrm{d}=$ number of respondents who scored 2

$\mathrm{e}=$ number of respondents who scored 1

The score of each answer summed, averaged, and grouped to determine the level of perceived public perception as follows:

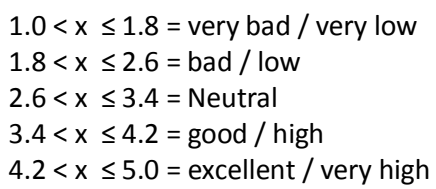

\section{Quality of Smoked Mackerel tuna}

Smoked fish samples from the research site was prepared (grouped, weighed and packaged in aluminum foil) and stored in a box. The samples were analysed at Laboratory of Faculty of Food Technology, University of Brawijaya. The proximate analysis (\% of wet weight) includes the level of ash, protein, carbohydrate, fat, and mineral.

\section{Water content}

Total of $2 \mathrm{~g}$ of sample dried in the oven at temperature $95-100^{\circ} \mathrm{C}$ to constant weight $\leq$ $100 \mathrm{~mm} \mathrm{Hg}$ for approximately 5 hours. Loss of weight in drying process reported as the estimate moisture level [17].

Water content $(\%)=\frac{\text { Weight loss during drying }(\mathrm{g})}{\text { sample weight }(\mathrm{g})} \times 100 \%$

\section{Ash level}

The ash level determined with the method of combustion in the furnace. Sample was burned at high temperatures of $500-600^{\circ} \mathrm{C}$. High temperatures burned the organic material and remained the ash. The ash level was determined as follow formula [19]:

$$
\text { Ash Level }(\%)=\frac{\text { ash weight }(g)}{\text { sample weight }(g)} \times 100 \%
$$

\section{Protein content}

Protein level determined using Kjeldahl method. Total of $0.75 \mathrm{~g}$ sample inserted into the Kjeldahl flask then added $6.25 \mathrm{~g} \mathrm{~K}_{2} \mathrm{SO}_{4}$ and 0.6225 $\mathrm{g} \mathrm{CuSO}_{4}$ as a catalyst. The next stage is the destruction process at temperature of $410^{\circ} \mathrm{C}$ for \pm 2 hours or until a clear solution is obtained. Kjeldahl Flasks mounted on a series of steam distillate apparatus and added $50 \mathrm{ml}$ of $\mathrm{NaOH}$ $40 \%$. Then distillate to fit in Erlenmeyer volume reaches $150 \mathrm{~mL}$ (distillate in green). Distillate titrated with $\mathrm{HCl} 0.2 \mathrm{~N}$ until the color changes into gray. Blanko were given the same treatment as the sample. Tests carried out in duplicate. The protein level was calculated by the formula [17]:

Protein Content $(\%)=\% \mathrm{~N} \times 6.25$

$\% \mathrm{~N}=\frac{\mathrm{ml} \mathrm{NaOH} \text { blanko }-\mathrm{ml} \mathrm{NaOH} \text { sample } \times \mathrm{N} . \mathrm{NaOH} \times 14.008}{\text { gram material } \times 1000} \times 100 \%$

\section{Carbohydrate level}

Carbohydrate level was calculated with method of by difference with formula [19]:

Carbohydrate Level $(\%)=100 \%-(\%$ water $+\%$ ash $+\%$ protein $+\%$ fat $)$

\section{Fat level}

Fat level of foods measured by Soxhlet method, which is used if the food contains relatively low fat. Total of $2 \mathrm{~g}$ of the sample wrapped in fat-free filter paper and put in a fat erlenmeyer. Sample refluxed for 8 hours until the solution is clear, that signified all the fat has been extracted. Fat content was determined using the formula [19]:

Fat Level $(\%)=\frac{\text { (final weight }- \text { initial weigth }) \text { of erlenmeyer }(\mathrm{g})}{\text { sample weight }(\mathrm{g})} \times 100 \%$

\section{Mineral level}

Porcelain bowl was heated in the oven at temperature of $105^{\circ} \mathrm{C}$ for 4 hours, and inserted into the desiccator for 15 minutes to be weighted with analytical balance. The first phase, $3 \mathrm{~g}$ sample crushed and inserted into the cup then performed first combustion in oven at $200^{\circ} \mathrm{C}$ for 2 hours. Next the cup put into the desiccator and weighed [19].

In the second combustion, it reincinerated at $350^{\circ} \mathrm{C}$ for 18 hours, and then put into a desiccator to be weighed. Combustion III, it reincirated on the furnace, and then the cup is inserted into the desiccator for 30 minutes to be weighed [19]. 


\section{RESULTS AND DISCUSSION}

Situbondo Local Wisdom on Smoked Processing

Smoked fish processing Unit of Small-Medium Enterprises (SMEs) in Jangkar village, Situbondo started since 1986 . The business unit constantly produce smoked fish, which is known as smoked fish of Jangkar. Processing is done traditionally, without salting process, on the smoked furnace made of cement and brick, with fuel of coconut coir. In the smoking process, they placed multiple midrib of banana stems on the furnace. The smoking adds a distinctive flavor to the product, even without additional herbs or spices. Interviews and direct observation on the smoking process showed some characteristics (Table 2).

Table 2. Characteristics of smoked mackerel tuna processing in Jangkar Village

\begin{tabular}{l|l}
\hline \multicolumn{1}{c}{ Parameter } & \multicolumn{1}{c}{ Characteristics } \\
\hline $\begin{array}{l}\text { a. Raw Materials } \\
\text { raw materials }\end{array}$ & Mackerel tuna. \\
& Jangkar Port (TPI Jangkar) and \\
Mimbo Port (TPI Mimbo), both \\
located in Situbondo.
\end{tabular}

\section{Traditional Smoked Processing of Mackerel tuna} Procedure of smoked mackerel tuna processing is as follows. First, fish weighed for $10 \mathrm{~kg}$, then cleaned and disemboweled. Fish was cut into small slices at its back to accelerate the cook. Prepared fish was arranged on smoking rack with midrib of banana stem horizontally after the coconut coir is burned and produces smoke (Fig. 1). Fish is smoked at temperature of $60-80^{\circ} \mathrm{C}$ for $10-30$ minutes duration (Fig. 2). Fish flipped in every 5 minutes. This traditional smoking method use no food additive or salting because tuna meat with a high fat content (1-3\%) will produce a savory taste when smoked.

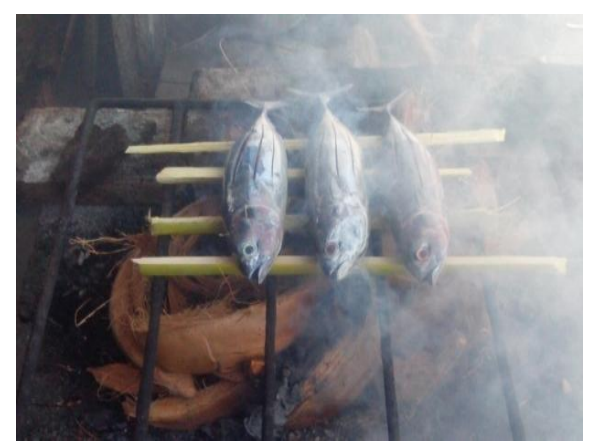

Figure 1. Smoked Mackerel Tuna

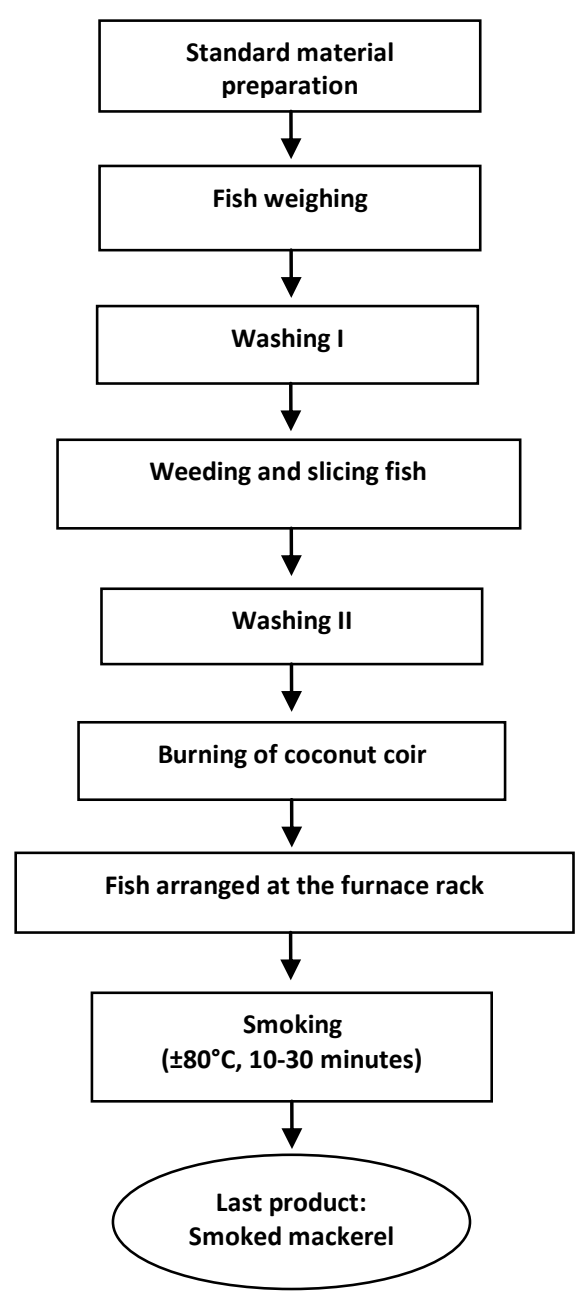

Figure 2. Process ot Smoked IVlackerel I una 
The traditional smoking procedure is slightly different from the National Standardization Board [17]. This smoking do not through the salting process and packaging process is done without cooling. It is different as reported by Heruwati [5], smoked fish should be quickly and evenly cooling after the smoking process before packaging, otherwise smoked fish will be mushy, moist and sour or moldy. Different smoking procedures influenced by properties of fish used, the local conditions and general level of technology [5]. Fish smoking process in Situbondo use a very simple technology as a part of the local indigenous. The addition of the midrib of banana stem on the furnace made of cement and brick is believed to give special flavor on the smoked.

\section{Characteristics of Organoleptic}

Evaluation on smoked mackerel tuna with organoleptic tests sensory attributes including; appearance, odor, flavor, texture and color [17]. The flavor compounds in smoked fish varied due to differences in raw materials, processing, storage, fuel materials and food additive. The results of organoleptic test has the average value of rating scale on 7-8 (Table 3).

Table 3. Organoleptic of smoked mackerel tuna

\begin{tabular}{|c|c|c|c|}
\hline No & Sensory & Average & Specification \\
\hline 1 & Appearance & 7.89 & $\begin{array}{l}\text { Intact, clean, } \\
\text { strong brown } \\
\text { specific color }\end{array}$ \\
\hline 2 & Flavors & 8.24 & $\begin{array}{l}\text { Fragrant, } \\
\text { adequate smoke, } \\
\text { no extra } \\
\text { disturbing odor }\end{array}$ \\
\hline 3 & Taste & 8.41 & Delicious, savory. \\
\hline 4 & Texture & 7.40 & $\begin{array}{l}\text { Solid, compact, } \\
\text { fairly dry, fairly } \\
\text { tight inter-tissue }\end{array}$ \\
\hline 5 & Colors & 7.20 & $\begin{array}{l}\text { Attractive, shiny } \\
\text { brown specific } \\
\text { color }\end{array}$ \\
\hline
\end{tabular}

The results showed that smoked mackerel tuna possess intact intensity, clean, very shiny brown color for specific type. This is supported by the use of coconut coir fuel with heat smoking methods that produce two times carbonyl compounds and phenols more than cold smoking method [20]. Carbonyl compounds and phenols contained in the smoke formed the color and odor of smoked fish.
Sensory attributes of flavor on smoked mackerel tuna demonstrated that odor intensity is adequate fragrant of smoke, without any additional disturbing odor. In this research, smoked mackerel tuna produced without any salt and food addition. Smoking process produce odors from the compound in natural raw materials, e.g. fat oxidation and hydrolysis give the characteristic aroma of the fishery products. Phenol compound is soluble in fat; more fat creates more delicious flavor.

Sensory attributes of taste on smoked mackerel tuna has flavor intensity of delicious and savory. It is influenced by the use of raw materials which categorized as fatty fish, thick and compact flesh, thus produce tasty smoked fish [15]. Meanwhile, according JICA [21] and Swastawati et al. [20], delicious taste that characterized the smoked fish products mainly derived from phenol and aldehyde compounds.

Texture on smoked mackerel tuna is solid, compact, fairly dry, and fairly tight inter-tissue. The use of heat smoking method in 10-30 minutes and smoke distance of $\pm 16 \mathrm{~cm}$ remained fairly high water levels in smoked fish. The mackerel tuna derived from sea water thus it has fairly high humidity and easily detached tissue.

Smoked mackerel tuna in this study has attractive color intensity, brown, and shiny specific types. Adawyah [4] explained that highquality smoked fish characterized by a golden brown color, yellowish brown rather thatn dark colors, spread evenly and specific types. The color change occurs due to the ongoing reaction between phenol components in the smoke with protein and sugar components in fish flesh.

\section{Public Perception on Smoked Fish Processing}

Assessment of public perception were grouped into three important criteria, i.e. knowledge on smoked mackerel tuna, flavor of smoked mackerel tuna, and preservation of smoked mackerel tuna processing (Table 4). Results Data Validity of the questionnaire instrument has a correlation value of $\geq r$ tables (0.213), which declared as valid and the reliability value of 0.734 which declared reliable.

Public knew well about the processing of smoked mackerel tuna. It implied from the results of the questionnaire which states that the processing of smoked mackerel tuna has been known to the public as a indigenous product in Situbondo regency since long time ago. The level of public knowledge is an important basis for local society to improve the welfare of their lives. 
As explained by Hakim [22], knowledge on the natural resources is important for living survival.

The distinctive flavor of smoked tuna is favored by the public. Good taste and flavor support the high interests of the public for the product. As stated by Stephen [23] that the success or failure of a product in the market, heavily influenced by the consumers preference on the product.

Table 4. Public Perception Assessment on Smoked mackerel tuna

\begin{tabular}{|c|c|c|c|}
\hline \multirow{2}{*}{ No } & \multirow{2}{*}{ Question } & \multicolumn{2}{|c|}{ Public Perception } \\
\hline & & Mean & Descr. \\
\hline & Knowledge of smoked tuna & & \\
\hline 1 & $\begin{array}{l}\text { Do you ever visit the beach of } \\
\text { Jangkar, Situbondo? }\end{array}$ & 4.09 & ever \\
\hline 2 & $\begin{array}{l}\text { Do you know the processing } \\
\text { of smoked tuna in Jangkar, } \\
\text { Situbondo? }\end{array}$ & 4.18 & knew \\
\hline 3 & $\begin{array}{l}\text { Do you know smoked tuna as } \\
\text { a tourism product? }\end{array}$ & 4.08 & knew \\
\hline 4 & $\begin{array}{l}\text { How is the level of freshness } \\
\text { of the used raw materials? }\end{array}$ & 3.81 & fresh \\
\hline 5 & $\begin{array}{l}\text { Do you know how the } \\
\text { smoked tuna processed? }\end{array}$ & 4.26 & knew well \\
\hline \multirow[t]{2}{*}{6} & $\begin{array}{l}\text { How strategic is the location } \\
\text { of smoked tuna processing? }\end{array}$ & 3.54 & strategic \\
\hline & $\begin{array}{l}\text { Flavor and taste of smoked } \\
\text { tuna }\end{array}$ & & \\
\hline 7 & $\begin{array}{l}\text { Do you ever try the smoked } \\
\text { tuna products? }\end{array}$ & 4.01 & Ever \\
\hline 8 & $\begin{array}{l}\text { Do you like the taste of } \\
\text { smoked tuna? }\end{array}$ & 4.18 & Like \\
\hline 9 & $\begin{array}{l}\text { How is the hygiene of the } \\
\text { processing? }\end{array}$ & 3.45 & adequate \\
\hline \multirow[t]{2}{*}{10} & $\begin{array}{l}\text { How is the packaging of the } \\
\text { smoked tuna? }\end{array}$ & 2.32 & $\begin{array}{l}\text { un- } \\
\text { attractive }\end{array}$ \\
\hline & $\begin{array}{l}\text { Conservation on the } \\
\text { processing method }\end{array}$ & & \\
\hline 11 & $\begin{array}{l}\text { Is this smoked tuna process- } \\
\text { ing is a form of local know- } \\
\text { ledge? }\end{array}$ & 4.25 & $\begin{array}{l}\text { strongly } \\
\text { agree }\end{array}$ \\
\hline 12 & $\begin{array}{l}\text { Do this smoked tuna is a } \\
\text { typical culinary of Situbondo? }\end{array}$ & 4.25 & $\begin{array}{l}\text { strongly } \\
\text { agree }\end{array}$ \\
\hline 13 & $\begin{array}{l}\text { Do you think the government } \\
\text { suppose to support the pro- } \\
\text { cessing of smoked tuna? }\end{array}$ & 4.26 & $\begin{array}{l}\text { strongly } \\
\text { need to } \\
\text { support }\end{array}$ \\
\hline 14 & $\begin{array}{l}\text { Do this smoked tuna process- } \\
\text { ing needs to be preserved? }\end{array}$ & 4.22 & necessary \\
\hline 15 & $\begin{array}{l}\text { Does the development of the } \\
\text { smoked tuna need to be } \\
\text { enhanced? }\end{array}$ & 4.32 & $\begin{array}{l}\text { strongly } \\
\text { need to be } \\
\text { enhanced }\end{array}$ \\
\hline
\end{tabular}

Well knowledge of public towards smoked mackerel tuna processing show a positive impact on conservation acts by the community in Situbondo. It implied in the results of the questionnaire that most respondents agree to conserved this traditional processing of smoked mackerel tuna. This knowledge and attitude are factors that influence public perception and public actions [24].

\section{The Quality of Smoked Mackerel tuna}

The results of the proximate analysis on the smoked mackerel tuna presented in Table 5.

Table 5. Proximate Results of Smoked Jangkar

\begin{tabular}{lc}
\hline Parameter & Content Level (\%) \\
\hline Water & 63.4 \\
Ash & 1.88 \\
Carbohydrate & 0.99 \\
Protein & 29.59 \\
Fat & 1.14 \\
Mineral & 2.89 \\
\hline
\end{tabular}

\section{Water Content}

The water content of smoked jangkar is $63.4 \%$. It was not appropriate according to the SNI maximum standard on the water content of $60 \%$ [17]. The water content is affected by the heat smoking method, with high temperature and in a shorter time. Crapo [25] explained that produced water content influenced by the smoking method that carried out on the fish products. Shorter duration of smoking reselt a remain high water content on the product. The water content of the product will also influenced by initial water content of the raw materials of the used fish species. Generally, the water content of mackerel tuna and skipjack amounted to $70.58 \%$ [26].

Water loss also depend on the surface character of the fish that exposed to heat, time and temperature of smoking, and the humidity and smoke rate [19]. These factors affect the amount of smoke that directly contact with the fish thus affect the heat and the amount of water loss from the product.

\section{Ash Level}

The ash content of smoked mackerel tuna is $1.88 \%$. The values correspond to standard of $\mathrm{SNI}$ [17] that ranged of $2-5 \%$. Ash is residual inorganic substance as result of organic materials combustion and describes the total amount of minerals in the material. Ash content and composition depend on the type of material and the combustion method [19].

Ash level in smoked fish is laso influenced by the content of minerals in the raw materials and minerals contained additives during the proces, such as the salting process. Ash level in this 
smoked mackerel tuna influenced only by the amount of the mineral content of the raw material fish. It is because this method excludes any addition of mineral such as salts.

Whittle and Howgate [6] explained that cold smoking with a relative long duration (6-12 hours)creates large loss of water content, less loss of fat content and less ash content. Cold smoking method produce a higher ash content than heat smoking method.

\section{Carbohydrate Level}

Carbohydrate level of the smoked Jangkar is $0.99 \%$. Carbohydrate levels were influenced by the carbohydrate content of raw materials and performed smoking process. Carbohydrate of fresh fish generally found in a small amounts, ranged of $0.5-1.5 \%$ [27]. In some studies, the the level of carbohydrates are often ignored because the low rate, which relatively has no effect. Nevertheless, carbohydrates have an crucial role on the quality of the fish during the smoking process.

\section{Protein levels}

The ash level of smoked mackerel tuna is $29.59 \%$, which is higher than the standard of SNI, i.e. 21-26\% [17]. Protein content influenced by the loss of water content of raw material during the process. Fish smoking with a longer duration cause a higher loss of water content, thus the measured protein will also be higher. It is also influenced by the number of ingredients that are added during the smoking process, e.g. salting. The percentage of total protein, fat and ash on smoked fish without salting increased due to loss of water during the fumigation [28].

The additive ingredients (e.g. salt) on fish will bind the protein in fish flesh and thus proteins and amino acids will react with a variety of different smoke components, such as carbonyl and phenol. Carbonyl in the smoke reacts with the amino acids and cause browning, formation of color and flavor, while phenol compounds reacting the denatured proteins.

\section{Fat Level}

Measured fat content will be higher if the fresh raw materials also has a initial high fat content. The difference of contained fat in fish body parts will also affect the measured fat content. According to the USDA [26], mackerel tuna has about $1-3 \%$ fat content in the back flesh and $10-30 \%$ on the abdomen flesh. The result of our smoked of mackerel tuna showed fat content of $1.14 \%$.

In the smoking process, fat and water will extracted thus shrinked physic will occur. Smoking duration affect the nutritional composition of fish, especially the fat content. High temperatures during the smoking process reduce the level of omega- 3 fatty acids. The content of unsaturated fatty acids in fish flesh also resulted in higher fish susceptible to oxidation during the smoking process. It reduced the nutritional functions derived from fatty acids. Heat smoking method produces a product with low fat level because it will melt out along with the water loss. Fat and water loss can also occur due to protein denaturation [27].

\section{Mineral Level}

Smoked mackerel tuna in this study has a mineral content of $2.89 \%$. Minerals have a major influence the cooking, compactness, intactness, softness, tenderness and flavor of the product. Mineral is responsible to the perception of flavor and increase the intensity of flavor. Minerals act as a flavor enhancer for other flavor components in food [26]. According JICA [21], a certain amount of mineral salt on smoked fish flesh solidify the inter-tissue connection, affect fat oxidation and flavor of the product.

Minerals will interact with proteins for improving water binding in the flesh. The heat smoking will produce a product with a higher mineral level. It decrease the possibility of intertissue to be detached, thus the rate of moisture loss of fish to be pressed (Kemal, 2000).

\section{CONCLUSION}

Smoked mackerel tuna in Situbondo are traditionally process based on local wisdom, seen in the use of materials and method. Organoleptic test classified the smoked mackerel tuna as a good flavor product. Local community understands well the knowledge of the smoked fish method. Further conservation action for smoked fish processing is strongly supported by local community. The smoked mackerel tuna has high water content, normal carbohydrate level, high protein, relatively normal fat content, low ash level, and $2.89 \%$ minerals.

\section{Suggestion}

Fishery product processing based on local knowledge needs to be conserved to characterize the culinary tourism of Situbondo area. The improvements are need on packaging, hygiene, 
marketing, and further research on the level of PAH. We recommend local government and related agencies to provide assisstantce for local producer that use this traditional processing to be more developed.

\section{REFERENCES}

[1]. Institute of Indonesian Maritime. 2010. Sea of Pantura is no longer blue. http:// indonesiamaritimeinstitute.org/2010/02/0 7/sea-pantura-no-blue-Anymore.html.

[2]. Statistic Center of Situbondo. 2013. Geographic data, population, agriculture, and industry. Center of Statistical Data and Information of Situbondo. Situbondo.

[3]. Adawyah, R. 2007. Processing and preservation of fish. Bumi Aksara. Jakarta.

[4]. Heruwati, E.S. 2002. Traditional fish processing: prospects and development opportunity. Journal of Agricultural Research 21 (3), 92-99.

[5]. Whittle, K.J., P. Howgate. 2000. Glossary of fish technology terms. Prepared Under Contract to the Fisheries Industries Division of the Food and Agriculture Organization of the United Nation. http://www.onefish.org/global/FishTechn ologyGlossaryFeb02.pdf.

[6]. Ministry of Maritime Affairs and Fishery. 2011. Production fish processed by type of processing in Indonesia of 2005-2008. http://statistik.dkp.go.id/download/book0 2.pdf. Jakarta: Department of General Fishery Products Processing.

[7]. Goverment of Situbondo. 2013. About Situbondo Regency. http://www.situ bondokab.go.id.

[8]. Haras, A. 2004. Effects of liquid smoke concentration and immersion against of quality fillet smoked Skipjack (Katsuwonus pelamis) and stored at room temperature. Master Thesis. Faculty of Fisheries and Marine Science, Bogor Agricultural University.

[9]. Wibowo. 2012. Local wisdom in maintaining environment (Case study of rural communities in the District Dawe, Kudus Regency). Journal of Educational Social Studies 1 (1).

[10]. Budijanto, S., R. Hasbullah, S. Prabawati, Setyadjit, Sukarno, I. Zuraida. 2008. Identification and security testing liquid smoked of coconut shell for food products. Journal of Agricultural Research 5 (1), 32-40.

[11]. Margono, T., D. Suryati, S. Hartinah. 2000. Processing of smoked fish product www.warintek.ristek.go.id/food_health/fo od/ piwp/fish_smoke.pdf.

[12]. Suhendar, U., T. Soewarno, Soekarto, S.P. Nurheni. 2010. Study marketing strategy smoked fish in unit public of activity Citayam-Bogor. Bogor Management 5 (2), 145-156.

[13]. Siswina M R. 2011. Chitosan As Edible Coating In Smoked Dumbo Catfish (Clarias gariepinus) Which Vacuum Packed During Room Temperature Storage. [Thesis]. Faculty of Fisheries and Marine Science. Bogor Agricultural University.

[14]. Atmaja, A.K. 2009. Application of liquid smoke redistilled in characterization Kamaboko of mackerel tuna (Euthynus affinis) assessment from the level of durability and consumer preference. Master Thesis. Faculty of Agriculture. University of Sebelas Maret. Surakarta.

[15]. Setyastuti, A.I. 2010. Change of smoked tuna quality (Euthynus affinis) using liquid smoke shell oil and liquid smoke during cold storage. Master Thesis. Faculty of Fisheries and Marine Sciences. University of Dipenogoro. Semarang.

[16]. Indonesian National Standard. 2009. SNI 2725.1:2009. Smoke fish-part 1: specification. National Standardization Board. Jakarta.

[17]. Swastawati, F. 2011. Visibility study and business smoked fish efficiency with liquid smoked farm waste. Journal of Economic Dynamics Development 1 (1), 18-24.

[18]. Winarno, F.G. 2007. Biotechnology of food. Mbrio Press. Bogor.

[19]. Swastawati, F., T.W. Agustini, Darmanto Ys.S., E.N. Dewi. 2007. Liquid smoked performance of lamtoro wood and corn cob. Journal of Coastal Development 10, 189-196.

[20]. Japan International Cooperation Agency. 2009. Indonesian fisheries statistic index. Ministry of Marine Affairs and Fisheries. http://www.dkp.go.id/index.php/ind/new s/1125/jica-download-book.

[21]. Hakim L. 2013. Tropical Ethnobotany: A practical guide for understanding humanplant interaction in tropical environment. University of Brawijaya. Malang 
[22]. Stephen, P.R. 1998. Organizational behavior. Prentice Hall Internasional Inc, New Jersey. New York.

[23]. Peter, J.P., J.C. Olson. 2000. Consumer behavior: consumer behavior and marketing strategy. 1 (4).

[24]. Crapo, C. 2000. Smoking fish at home. http://www.uaf.edu/ces/publicationsdb/catalog/hec/FNH-00325.pdf.

[25]. United States Department of Agriculture. 2013. Calories in Smoked Fish and Nutrition Facts. National Nutrient Database 18. http:// http://www.nal. usda.gov/calories-nutrition/usda/smoked fish.

[26]. Kemal, P. 2000. Smoked fish. Jakarta: women information center in development PDII-LIPI in cooperation with Swiss Development Cooperation. 1-6.

[27]. Smith, B.A. 2004. Flavor formation from amino acids in fermented dairy products http://www.library.wur.nl/wda/dissertati ons/dis3574.pdf.

[28]. Suwamba, D. 2008. Boiling process using the concentration of different salt. http://www.smp-saraswati-dps.sch.id/ index. php/2008/ 